\title{
The Russian language as a mode of self-identity cultivation in the Russian émigré community
}

\author{
Ekaterina Shvagrukova $^{1, a}$, Elena Novikova ${ }^{2}$ \\ ${ }^{1}$ Tomsk Polytechnic University, 634050 Lenin Ave., 30, Tomsk, Russia \\ ${ }^{2}$ Tomsk State University, 634050 Lenin Ave., 36, Tomsk, Russia
}

\begin{abstract}
The research is devoted to the problems of the language adaptation of the Russian émigré community (1917-1940) abroad. It is conducted in the framework of sociology of literature, therefore, sociological terminology and definitions are used. The Russian language is considered in the context of the notions «assimilation» and «denationalization» in a particular historical period. The novelty of the investigation consists in studying the Russian language as an object of special reflection for the Russian literary emigration of the «1-st wave» and its creative instrument. The literary émigré community tries to rethink the role of the native language, its functions and the peculiarities of it use in the émigré environment. The Russian language becomes the object of discussion in various literary genres: contemplations about the language could be met in fictional prose and poetry, in memoirs, and in the epistolary genre. Different positions of the older and the younger generations are analyzed corresponding to the use of the Russian language as a tool of social and cultural memory and a mode of keeping the national self-identity.
\end{abstract}

\section{Introduction}

The representatives of Russian literature, who happened to appear abroad after October Socialist Revolution (1917) and formed the literary emigration of the «1-st wave» (1917-1940), faced a serious problem of keeping the native language. This problem included pragmatic as well as moral, ethical, cultural and aesthetical aspects. This issue was typical, particularly, for that historical period as far as the subsequent "waves» of Russian emigration differed in their aims of stay abroad. Therefore, cultivation of the Russian language did not become the main task for the emigrants of the «2-nd» and «3-d waves» as it had occurred with their predecessors. The language problems were closely interrelated with the issue of self-identity of refugees and expatriates, who had to experience a forced substitution of motherland and culture for a new place of residence and cultural environment.

\section{Materials and methods}

The language of the Russian émigré community has already become the object of the research in the works of various scientists (L. Isurin et al [1], K.A. Noels [2], P. Auer [3], B. Ige [4], J. Glad [5], B. Cormie [6], etc.). The issues of self-identity are also well-studied (for example, the papers of M.J. Horowitz [7], M. Rubins [8], R.

\footnotetext{
${ }^{\mathrm{a}}$ Corresponding author: shvagrukova@tpu.ru
}

Brislin[9], etc.). However, the investigations have been mostly conducted by linguists. This paper is of a multidisciplinary nature, and it considers the Russian language within the framework of sociology of literature. So, Russian is analyzed as an object of reflection, a creative instrument of writers and poets, and a mode of self-identity cultivation, in general. The methods used in the paper are as follows: descriptive, comparative, sociological, cultural and historical ones. The writings of I. Bunin, I. Odoevtseva, V. Nabokov, N. Berberova, V. Yanovsky and other representatives of Russian emigration are used as an analytic material in the given research.

\section{Results and Discussion}

Living out of Russia required expatriates and refugees to be adapted to the facts of new place of residence, and this necessity led, inevitably, to cultural and language assimilation of apatrides.

While analyzing the processes of emigrants' adaptation abroad, scientists speak in two basic terms: "denationalization" and "assimilation". In this paper these terms are used as a part of sociological definitions.

Denationalization (lat. de - a negative particle + natio - folk - hereinafter, the word-based translation is mine - E. Shvagrukova) within the sociological meaning 
is «1. Loss of national peculiarities (culture, language, etc.). Deprival of nationality, alienation of nationality» [10]. In the process of denationalization a person loses mechanically the contacts with a native nation. Consequently, the native culture and language are alienated, and the boarders of national self-identity are degraded. However, a person keeps passive language skills and memory about motherland.

Assimilation (lat. assimilatio - assimilation) within the sociological framework is «the process whereby individuals or groups of differing ethnic heritage are absorbed into the dominant culture of a society» [11]. Assimilation provokes the total loss of initial national identity and its substitution to a new one, which has been initially alien for a person.

For denationalization as well as assimilation the concept of language is crucial, because language is an indispensable part of culture for any nation, and it operates as an instrument creating a unified communicative environment.

Considering the historical situation of the Russian emigration of the «1-st wave», it is possible to mention only partial denationalization of the Russian émigré community abroad caused by involuntarily resettlement. The majority of Russian emigrants had a principle to retreat from assimilation. Particularly, the system of Russian national schools and universities was established in order to keep national identity together with the Russian language and culture, book publishing houses and libraries were oriented to Russian clients, many national arts had been developing, and Russian cultural heritage had been kept.

By the aid of the «Russian territorial city committee of help for Russian citizens abroad» («Zemgor») (19211941) Russian emigrants, even after the loss of the motherland, stayed in a well-ordered national community, which looked like a special self-sustainable world with the rules of behavior, relations and hierarchy typical for Russia.

On the one hand, it would be reasonable and wise for expatriates to refuse a native language in favour of the language spoken in the place of residence. However, Russian speaking emigrants, in bulk, at the initial stage of their wandering were not ready to part with Russian, which was so habitual and handy one. Having experienced the loss of the motherland, they tried to save the remnants of Russian culture with the help of the Russian language. It had transformed into the symbol and analogue of the gone culture and literature, and it was perceived as one of the most important means of self-identity keeping. The researcher E. Menegaldo refers to the following fact: «Endless love of the Russian Diaspora to the native language induces to turn June, 6, the birthday of Pushkin, into the national festival» [12]. The Russian language helped to save memories about the richest culture of the past, and about the society that had disappeared forever.

Due to the threat of assimilation and denationalization the Russian émigré community had realized the value of the native language. The Russian language was understood by the emigration of the «1-st wave» as one of the main means, which united the
Russian Diaspora abroad within the boundaries of the shared national culture and assured liaison with the motherland.

However, any language is an extremely delicate living organism being affected by many factors externally; it should be saved and cultivated. For this reason the branchy infrastructure of Russian speaking schools and other socially significant organizations had been developed. Thus, emigration tended to a certain disintegration and isolation against the external world in order to keep national self-identity and social and cultural memory abroad. The Russian language operated as a tool that helped to organize somehow the Russian émigré community allowing people to keep the structure and relations approved in the Russian pre-revolution society.

Russian poets and writers appeared to be in the more intricate position abroad than that of the representatives of the other art forms, namely, music, art, theatre, etc. N.N. Berberova in the book «The italics are mine: Autobiography» says: «Painting, theatre, music ...lived more normal life, because they merged - one way or another - with the European stream (painting - more, music - less)»[13]. Russian art, music, ballet, and theatre had been widely known abroad even before the October Socialist Revolution thanks to famous composers, artists, and public figures such as I. Stravinsky, V. Kandinsky, F. Chaliapin, S. Diaghilev and many others. The given arts crossed national barriers easily, because they were intended for audio- and visual perception of information.

In their turn, Russian writers had to solve a question of principle: to continue creating texts in Russian addressing to a lost Russian reader, namely, to write for nobody ("for the drawer"), or to change the language in order to get the access to the western readership.

The Russian language had transformed into a special object of reflection for the Russian literary emigration, which tries to give meaning to its role, function and to understand the specificity of its usage in the émigré community. Russian became the object of discussion in various literary genres of the «1-st wave» emigration: speculations about language could be found in fictional prose, poetry, memoirs, and the epistolary genre.

So, in the memoirs «On the banks of Seine» I. Odoyevtseva mentions the dialogue between P. Pilsky and G. Ivanov about Russian pronunciation: «Pilsky nods...

- But it is impossible to rhyme "bezzvuchno"("soundlessly") and "skuchno" ("wearily")». Indeed, it is necessary to pronounce "skushno"... But Georgy Ivanov does not agree.

- Sorry, but it was in Moscow where people said "skushno", and at our place in Petersburg - "skuchno". In this case we should say "ya skushayu" instead of "ya skuchayu"(I am bored). Whoever heard of that "ch" transfers into "sh"? And here one of the usual emigrant debates is ready to come about how it is necessary to say and about pronunciation» [14]. The keen interest of the interlocutors in the subject matter of the dispute, the excitement of their arguments, and a remark about the "commonness" of this talk proved that similar talks were a widespread phenomenon in the émigré community, the 
representatives of which tried not only to keep the active language in memory, but also to save variations of the Russian pronunciation. In the paper [15] E. Shvagrukova gives the following example characterizing the attitude of the émigré community to the Russian language. V. Nabokov in his story «The Circle» tells about a heroemigrant, who suddenly met his first childish love abroad: "And now, listening to a girl, who was answering to mother's questions with marvelous native melodiousness, he managed to think spitefully: "I dare say, now they do not have money to teach foreign languages to children", in other words, he had not grasped at once that now this language was, namely, the most leisured, the best luxury» [16]. The Russian language was not a natural necessity any more, from an ordinary thing it transformed into an exotic and delicate treasure, which should be kept safe, because it was disappearing rapidly.

$\mathrm{N}$. Berberova in her autobiography gives the example demonstrating fatal deprivation of Russian language mutual understanding among the children of Russian emigrants: «A teacher complaints that they do not understand «Gore ot uma» («The Mischief of being clever»), especially, about "chay"("to hope", the homonym to the word "tea" - the comment is mine E.S.): "Not due to sickness, hope, to boredom" - what is the tea? What is the sickness cured by it? Who drank it? What for? You need to explain each word» [13]. A Slavic form of the verb "chayat'" in the meaning "to hope, to look for" has already been receded in the memory of the children having appeared in the alien language environment. Language assimilation occurs, and it is necessary to make efforts in order to keep the Russian language. And Russian emigrants, in fact, make these efforts. They send their children to Russian schools, which have been established abroad, though it would be more reasonable and logically relevant to send them to local French or German schools for adaptation facilitating. But the Russian language and schools work as a frame hardening the Russian émigré community abroad.

One of the issues, being discussed by Russian literary emigration the most actively, had suddenly become a problem of ignorance of a foreign language or bad foreign language proficiency. Traditionally, it was considered that Russian refugees spoke foreign languages perfectly, and they did not have any language barrier while their removal abroad as far as, in bulk, they were well-educated people with a high level culture. Nevertheless, a lot of evidence could be met in émigré literature of fiction and non-fiction genres, which proved the contrary.

Thus, V. Yanovsky in his memoirs «Champs Elysees. The Book of Memory» tried to explode a myth about the good knowledge of foreign languages among the Russian emigrants: "Generally, the legend that Russians can speak many foreign languages fluently lives, I hope, its last years» [17]. Then, he enumerates the names of famous Russian writers and poets demonstrating a bad proficiency in the language of a resident country (V. Khodasivich, I. Bunin, etc.).
N. Berberova in the autobiographical book says about French: «...it was the language, which I knew, but suddenly it had appeared to be hardly the same as I was taught in my childhood: it was exquisitely complicated, with the barriers that threw me back from it ever and again» [13]. This explains the difficulties in language barrier overcoming. The autobiographical character of V. Nabokov Martin Edelweiss in the novel «Podvig» («Glory» in English) experienced the similar problem while his study at Cambridge: «He remembered and said the words that ten years ago were popular with English schoolboys, and now they have been considered either vulgar or laughably old-fashioned»[18].

Unexpectedly, Russian emigrants had known that during their childhood in Russia they learned a simplified invariant of a foreign language, which had not been changed for decades. Meanwhile, at home this language continued to develop and change as a living organism.

In poetry this problem also has its reflection. $\mathrm{N}$. Otsup writes a poem "Emigrant» about troublesome doubts of a man having abandoned his homeland: «But an alien language is exhausting. And we have not got used to its excessive doses» [19]. A narrator dissociates himself from his new environment intentionally, in spite of its evident advantages and benefits. A native language becomes a factor separating the personage from the world around.

Therefore, the lack of language proficiency appeared to be a pragmatic reason for native language keeping, which led to willful self-isolation of the Russian emigration of the " 1 -st wave". «Even the very first descriptions of Russian emigrants are hinged on their social privacy and unwillingness to assimilate in a new environment» $[20]$.

The representatives of the «older» and the «younger» generations of literary emigration solved the problem of the language use in different ways. Successful writers and poets (such as I. Bunin, B. Zaytsev, A. Kuprin, M. Tsetaeva, V. Khodasevich, G. Ivanov, etc. ), who had become famous and won the recognition in the Russian Empire, were not ready to refuse the Russian language as the last tie with their motherland and Russian culture. The language exchanged provoked, from their point of view, the absence of a creative nutritional medium and the loss of a professional instrument.

While talking to G. Adamovich and having known that the critic was going to write in French, I. Bunin said: «Write the language that you were born with and grew up. A man cannot know two languages. ... To know, to feel every detail, every shade of meaning...» [21]. This relation to the Russian language was principle for I. Bunin as well as for many other representatives of the «older» generation. Firstly, it was determined by the material that was used as a basis for creative works of Russian writers. Emigration as a source of tragedy could not become an inspiring environment for them, and, mostly, the writers used the material of the Russian Empire, like Bunin, or turned to even further past, for example, like B. Zaytsev with his «Venerable Sergiy Radonezhsky» and "The life of Turgenev», or A. Remizov with his mythogenesis and folklore. The 
Russian material required its creative manifestation in Russian, and emigration «...did not acquire its portrayer of ordinary life» [22] by the words of K. Mochulsky, a famous critic of Russian literary emigration.

In their turn, young writers (V. Nabokov, V. Yanovsky, H. Troyat, I. Odoevtseva, etc.) demonstrated much more flexibility and made the attempts to write in a foreign language. However, only few of them could achieve success and recognition, particularly, Nabokov and Troyat, who were bilinguals. Also, they were called "writers-amphibians» [22] due to pretended easiness of transfer from the native language to another one. This transfer to a foreign language as a creative tool was caused by different reasons, for example, the lack of opportunities to publish writings in Russian, the absence of readers, and poverty (I. Odoevtseva), the move to the USA (V. Yanovsky), assimilation (H. Troyat). As to the imaginary easiness of this transfer, V. Nabokov described this necessity the best: «Transferring to another language, I refused this way not the language of Avvakum, Pushkin, Tolstoy - or Ivanov, nanny, Russian publicism, in a word, not a common language, but an individual, intimate dialect» [23]. Nabokov declared in this citation the freedom from the Russian literary tradition and highlighted the function of a native language as a tool for creating texts. Meanwhile, the work with the help of a new instrument turned to be hard and painful, and the writer needed 15 years to achieve world-wide fame and recognition due to the book written in English («Lolita»).

At the same time, not all the representatives of the "younger" generation decided to change a native language in order to broaden the readership, even if they knew foreign languages perfectly. For example, G. Gazdanov, who spoke French fluently, created his works in Russian, but within the framework of the French literary process, so he got the reputation of «a French author, writing in Russian» $[24]$.

In spite of a tendency to self-isolation, creative intellectuals needed to get a foreign audience and foreign readers, but very often they encountered some obstacles caused, on the one hand, by indifference of local population to alien art, and, on the other hand, by the refuse of Russian authors to write in foreign languages. Meanwhile, Russian literature abroad was influenced, inevitably, by the western literary process, therefore, the poetry of B. Poplavsky, was compared by foreign critics with those of P. Verlaine and A. Rimbaud, and the early writings of $\mathrm{V}$. Nabokov were called the imitation of French and German patterns.

\section{Conclusion}

Generally, each representative of the literary emigration solved the problem of a language according to his worldview, whether it was V. Khodasevich with his tendency to keep Russian classical poetry, A. Remizov with his neologisms and myth-making, or V. Nabokov, who being a student of Cambridge, studied «a secondhand copy of Dahl' Interpretative Dictionary of the Living Russian Language in four volumes», because «...fear of losing or corrupting, through alien influence, the only thing I had salvaged from Russia - her language - became positively morbid»[25].

The Russian language helped Russian émigré community to perform a mission, which was contained in maintenance and cultivation of the Russian social structure and Russian culture abroad. But, additionally, the constant use of Russian provoked the self-isolation of the Russian émigré community from the foreign society and culture.

The issues of keeping the Russian language in isolation from Russia, the possibilities for its improvement and creative potential development were extremely important for the Russian literary emigration of the "1-st wave", they caused controversy and left an imprint on many writings of various literary genres.

\section{References}

1. L. Isurin, M. Furman, K. White, Lang\&Com, 40, (2015)

2. K.A. Noels, Lang\&Com, 35 (2014)

3. P. Auer, IJB, 3, 4 (1999)

4. B. Ige, JoP, 42, 11(2010)

5. J. Glad, Russia abroad: writers, history, politics (1999)

6. B. Comrie et al.- Comrie B., Stone G., Polinsky M. (eds.) The Russian Language in the Twentieth Century (1996)

7. M.J. Horowitz, JRP, 8, 2, M14 (2014)

8. M. Rubins, SlavRew, 73, 1 (2014)

9. D.P.S. Bhawuk, R. Brislin, IJIR, 16, 4 (1992)

10. Denationalization// URL: http://encdic.com/fwords/Denacionalizacija-11591.html Digital resource. Accessed date:1.09.2015

11. Assimilation//

URL: http://global.britannica.com/topic/assimilationsociety Digital resource. Accessed date:1.09.2015

12. E. Menegal'do, Russkie v Parizhe 1919-1939 (2001)

13. N.N. Berberova, Kursiv moj. Avtobiografija (2014)

14. I.V. Odoevtseva, Na beregah Nevy. Na beregah Seny (2012)

15. E.V. Shvagrukova, V mire nauchnyh otkrytij, 5.8, (2015)

16. V.V. Nabokov, Krug. Sobr.soch. v 4-h tomah. T.4 (1990)

17. V.S. Yanovsky, Polja Elisejskie. Kniga pamjati (1993)

18. V.V. Nabokov, Podvig, Sobr.soch. v 4-h tomah. T.2 (1990)

19. Yu.N. Bezelyansky, 99 imen Serebrjanogo veka (2009)

I. Kaspe, Iskusstvo otsutstvovat': Nezamechennoe pokolenie russkoj literatury (2005)

20. G.V. Adamovich, Somnenija i nadezhdy (2002)

21. O.M. Mihajlov, Literatura russkogo zarubezh'ja (1995)

22. V.V. Nabokov, Drugie berega. Sobr.soch. v 4-h tomah. T.4 (1990) 
23. E.

Bal'zamo,

URL:

http://www.ruspole.info/ruzhi_podshivka/2003

Digital resource. Accessed date:1.09.2015 (2003)

24. V.V. Nabokov, Speak, memory! (1989) 